Article

\title{
WORKERS AND MILITANT LABOUR ACTIVISTS FROM PUNJAB IN BENGAL (1921-1934)
}

\author{
SUCHETANA CHATTOPADHYAY \\ Jadavpur University (Kolkata, India)
}

\begin{abstract}
Sikh migrants joined post-war strike-waves, formed unions and turned left in the 1920s and early 1930s in and around Calcutta, in the South Bengal region under British rule. To them, an unofficial commemoration of Komagata Maru's voyage and the militancy associated with the Ghadar movement during First World War, became inseparable from contemporary resistance to the domination of colonial capital and British colonial state in India. They engaged with, worked upon and simultaneously moved beyond the boundaries of ethno-linguistic and religious identities as well as the social content of anti-colonial nationalism by focusing on a self-aware identity based on organised class action. This understanding was linked with the lived experiences of migration and imperial exploitation, the components of identity that had come to the forefront during the war. The diasporic identity of the Sikh migrant workers converged with the wider labour movement and was politically reshaped in the post-war context as livelihood issues took on the form of systematic protests in the city and beyond.
\end{abstract}

\section{Keywords \\ Komagata Maru, Ghadar, Sikhs, Punjab, migrants, Bengal, labour, militancy, inter-war, communists, Gurdit Singh, Bengal Kirti Dal}

\section{Introduction}

The Komagata Maru's arrival in 1914, the confrontation with colonial state power and the massacre of 21 Sikh passengers at Budge Budge, the repressive measures adopted by the colonial authorities on Punjabi migrants and the local Punjabi Sikh inhabitants, and the influence of Ghadar, prompted a handful of Sikh workers to participate in short-lived revolutionary actions in and around Calcutta during First World War. The minute and predominantly working-class Sikh migrants were chiefly visible in the neighbourhood of Bhabanipur and the Khidirpur dock area in Calcutta and Howrah, Calcutta's industrial urban twin. The activists who joined the underground lived, earned their livelihoods and developed a degree of social support and political network distributed across these geographies of local labour concentration. They were drawn from the ranks of cab-drivers, chauffeurs, janitors and tailors, all of derooted peasant background and some with military experience as former soldiers. Their transterritorial consciousness from below was 
shaped by the migratory appeal of Ghadar as a movement of labour and popular revolt stretching from Burma to China to the Pacific. While moving back and forth from one region to another, they had become familiar with individuals, literature and ideas bearing programmes of a revolutionary overthrow of the colonial regime. Calcutta and Howrah became connected, through them, with the diasporic revolutionary movement brewing in the British port-cities, colonies of South East Asia and further East in China, Japan and North America. Though they were suppressed (IB 454/1916 (13/16) $)^{1}$ the horizon of post-war political landscape in Calcutta and its surroundings was extended and altered by anti-colonial mass movements, labour activism and the emergence of the left. This was also the period when migrations from Punjab and the size of the Sikh labour-force increased. To the Sikh migrants who joined post-war strike-waves, formed unions and turned left in the 1920s and early 1930s, an unofficial commemoration of the Komagata Maru's voyage, and the militancy associated with the Ghadar movement, ${ }^{2}$ became inseparable from contemporary resistance to the domination of colonial capital. They engaged with, worked upon and simultaneously moved beyond the boundaries of ethno-linguistic and religious identities and the social content of nationalism by focusing on a self-aware identity based on organised class action. This understanding was linked with the lived experiences of migration and imperial exploitation, the components of identity that had come to the forefront during the war. The diasporic identity of the Sikh migrant workers converged with the wider labour movement and was politically reshaped in the post-war context as livelihood issues took on the form of systematic protests in the city and beyond.

\section{Post-War Upsurge}

The Sikhs in Calcutta, ${ }^{3}$ classified by colonial census-makers as the practitioners of one of the "minor" religions, worked mostly as sepoys and traders during the first decade of the twentieth century. A marked increase of the Sikh population was registered during this period. The majority had migrated to the city since 1901 (O’Malley 1913a, 20-26). In 1911, 980 Sikhs lived in Calcutta and its suburbs; they fell within the wider population of 1,743 Punjabi emigrants and included 171 Sikh women. Most Sikhs were adult men of a working age, between 20-35 years (O'Malley 1913b, $14,28)$. Ten years later, the population of Sikhs rose to 1,485 ; while they continued to engage in business, the number of soldiers declined. Instead, many came to be employed as taxi cab-drivers. The drivers and owners of "mechanically driven vehicles" and their families lived in Calcutta and

\footnotetext{
1 "IB" stands for Intelligence Branch of Bengal Police. These documents are from the West Bengal State Archives in Kolkata.

${ }^{2}$ For a pioneering and brilliant study of Ghadar against the backdrop of agrarian poverty and migration from Punjab, see Puri 1983. Also, Sood 2000; Deepak 2001, 61-85; Ramnath 2011. For an account of Komagata Maru's journey, see Johnston 1995. Also, Tatla 2007.

${ }^{3}$ For a survey of the Sikh diaspora in Calcutta, see Banerjee 2012.
} 
Howrah; the Sikh chauffers were classified within them (Thompson 1922, 38-39). ${ }^{4}$ With the introduction and increase in motor vehicles during the second decade of the century, the pattern of Sikh employment changed. Inside the Calcutta municipal area, the highest concentration of Sikhs was in Bhabanipur. They were also to be found, probably employed as sepoys, in Fort William and the maidan. The rest were scattered across Jorasanko and Kolutola in the north, Ballygunge and Tollygunge in the south and Garden Reach, the industrial suburb of Calcutta associated with shipping. Half of the male population was unable to read and write, illiteracy was very high among women and the population consisted mostly of working men between the age of 20 and 40 years (Thompson 1922, 10, 17, 28).

Labour upsurge of the late 1910s and the early 1920s found resonance among them; labour was incorporated by the ongoing Non-Cooperation and Khilafat Movements, the chief vehicles of popular anti-imperialism. The post-war mass upsurge was guided by the demands for India's selfgovernment and the protection of the Ottoman Caliphate, the headquarters of Sunni Islam, from Anglo-French invasions. In this wider climate of Hindu-Muslim unity and populist militancy, ${ }^{5}$ the echoes of the Ghadar tendency from the war years resurfaced and the protest-mentality of the postwar years showed signs of spreading in the colonial army. In 1921, Santa Singh of Ludhiana, sepoy and driver of 23rd Indian Mechanical Transport Company, was charged with spreading disaffection in the ranks. He had "used words in favour of the Khilafat Committee and Non Cooperation, and was found guilty and sentenced to suffer rigorous imprisonment for two years." He had complained of poor wages, urged other soldiers to resign, promised better-paid work with the Khilafat Committee and advocated wearing of "swadeshi or Gandhi cloth" in late October 1921. At his court-martial in late November 1921, one Havildar, 2 Lance Naiks and 2 Sepoys of the same company testified against him and he claimed in defence that they were his enemies, having harboured personal hostility towards him. He served time in the Alipur Central Jail, a familiar destination of political prisoners in the city. In 1923, "an officer reported that he seemed very discontented, and that he was met by several motor car drivers on his release." During the months that followed, he briefly went back to his village, returned and received a taxi-driver's license in Calcutta; he travelled briefly to Rangoon to stay with his brother, a milk-man and his movements were watched closely; finally, he again came back to Calcutta to take up the occupation of a private car driver, finding employment at 4 Russell Street (IB 454/1916 (13/1916)). Others had tried to organise risings within the army during the war. Influenced by the post-war anti-imperialist mass movements, Santa Singh had encouraged mass resignation from colonial service, an altered strategy to weaken the Empire. The transition from a recalcitrant sepoy-driver to a civilian transport worker, his journey from the army barracks to the Alipur Jail to Punjab and Rangoon and his return to Calcutta, the aim of sowing "sedition" in the ranks of the army at a time of

\footnotetext{
${ }^{4}$ Maidan was the open space at the centre of the city, adjoining the Europeanised Chowringhee and Dalhousie areas of imperial urban governance and commercial control.

${ }^{5}$ For details on the context and trajectory of the twin mass movements launched in India after the First World War under Gandhi’s leadership, see Sarkar 1983, 165-227.
} 
organised anti-colonial upheaval resonated similar patterns and movements from the immediate and distant past. The accumulated experiences of rebel soldiers of the preceding century, of Pathan and Sikh soldiers who had supplied British colonialism with military labour and been courtmartialled for defying the imperium's authority or those who had left the army, had filtered down across the decades; they had directly and indirectly touched the route he had taken.

The Sikh presence in the service sector as drivers explains their participation in the postwar world of strikes and union-formation. The taxi-cab and the private cars plying in the streets had come to symbolise speedy transport and urban luxury. Those who drove these vehicles, in contrast, suffered from low pay and police repression. During the strike-wave of 1920-21, as protest mentality of industrial and service sector workers found an organised outlet in a climate of material hardship, the taxi and professional motor-car drivers went on short-lived strikes and displayed a tendency to step beyond the restraints imposed by the mostly middle-class labour leaders. 150 drivers employed by Indian Motor Taxi Cab Company went on strike during 12-14 December 1920. They demanded a rise in their commission from 11 percent to 15 percent, smaller deduction for empty miles when cabs ran without passengers and dismissal of oppressive supervisory staff. They alleged that the firm had not fulfilled its promise to raise their commission to 12 and a half percent; this was the term of settlement reached, leading to an end of the strike. This strike was followed, a month later, by a longer strike, involving 3000 taxi drivers and professional drivers of private cars in Calcutta during 12-26 January 1921; this was a direct result of protracted differences with the police over new regulations. The rules directly interfered with the livelihoods of the workers by prohibiting the practice of carrying attendant-companions and imposing medical checks on drivers which adversely affected those who were older. During September-October 1920, the association of taxi and private automobile drivers had objected to the new regulations being planned in writing to Police Commissioner of Calcutta. A situation of confrontation emerged whereby the workers tried to cling to the existing working conditions, opposing police interference through strategies of attrition while the police tried to change and control them and their working conditions. On 2 January, the association held a meeting at Town Hall. It was decided that a strike will begin on 26 January unless a fresh petition being sent to the Police Commissioner led to a favourable reply by 25 January. On the night of 11 January 1921, the mood of labour militancy suddenly escalated when Issur Singh, a taxi-driver was arrested and hauled to a police station for "continued disobedience of the traffic police officer" and refusal to show his license. Other drivers on the spot protested against his treatment and immediately went on strike. By 12 January, all taxidrivers of the city had stopped work. Though this was "a breach of programme," the strike was endorsed by their association. On 16 January, a mass meeting of strikers at Wellesley Square under auspices of the association spoke on the negative implications of the new regulations, particularly medical tests on existing drivers, making it practically impossible for many to work. The strikers also successfully appealed to the drivers of private cars to join the action. In the face of widening protests, the Police Commissioner announced he had recommended the appointment of a committee of enquiry to look into the rules, will allow attendants unconditionally and accept the medical certificate of any doctor, depending on the committee's report. He also agreed to receive 
a deputation of strikers in order to reach a negotiated settlement. On 18 January, the strikers reassembled at Wellesley Square. As the leaders briefed them on the meeting with police authorities, they were frequently interrupted by shouts from strikers that they will not accept medical tests and will carry attendants who did not possess a license. They also demanded a withdrawal of the case against Issur Singh. On 20 January, the Commissioner agreed to drop medical examination of old drivers, if the committee of enquiry agreed and issued a communiqué announcing its formation. This conciliatory strategy was abruptly abandoned the next day when the government suspended all existing driving licenses of motor cars. The President of the association, along with the owners of automobiles, now began a negotiation with the Commissioner. The President agreed to drop the demand regarding Issur Singh's case on 22 January. On 24 January, the association and the owners accepted the Commissioners' proposals and the suspension order on driving licenses was lifted. The drivers returned to work on 25 January, having prematurely started and ended their strike. The results of industrial actions demonstrated uneven gain. While the stoppage of work directed against a specific concern in December 1920 by taxi-drivers secured higher earnings, the joint cease-work by taxi and private car drivers in January 1921 failed to overturn new police regulations. ${ }^{6}$

The life of a taxi-driver as a worker, mostly Sikhs from Punjab, was subject to continuous police interference. The police apparatus, acted as a managerial force on behalf of the colonial authorities and business enterprises, with the aim of replacing older drivers and vehicles as disposable labour and outdated means of service against a backdrop of rapid growth in productive forces which benefitted the owners rather than the workers; the aim was to control the work-force physically and impose curbs on used vehicles, the instruments of service-production which most drivers, as workers, did not own. Aging drivers and automobiles became the chief targets of police authorities. The police attempted to legitimise the measures of control in the name of road-safety and "standardisation" of taxi services. By 1918, the numbers of motor vehicles in Calcutta streets were over 5000, including motor-cycles. A "regrettable rise in fatal accidents" was also registered. In the course of the 1920s, the government plans to control and regulate the taxi-trade were implemented. The number of people injured and killed from collision with taxi-cabs kept rising between 1920-22 despite these restrictions, confirming that they were not aimed at saving lives but increasing the control of the government and entrepreneurs over the profitable transport sector and often recalcitrant drivers. By 1923, the rules had taken effect. In 1928, a huge increase in the trade was recorded and further regulations were imposed on cabs. These restrictions did not lead to immediate protests. The work-force, in the absence of a surge in labour resistance, was forced to adapt to the changes, and may have seen a rise in earnings. The police thought that there had been an increase in the number of licenses of all kinds due to a surge in motor traffic and higher income for drivers, as they were needed while sectoral expansion in their line of work was taking place. ${ }^{7}$

\footnotetext{
${ }^{6}$ Report of the Committee on Industrial Unrest in Bengal 1921.

${ }^{7}$ Annual Reports on the Police Administration of the Town of Calcutta and its Suburbs for the year 1918-1928.
} 


\section{The Turn Leftwards}

Work as a realm of intensified labour exploitation, made way for an affinity towards political radicalism. From the second half of the 1920s, an identifiable left tendency emerged among the Sikh workers living in the city and the suburbs. In November 1927, during the birth anniversary celebration of Guru Nanak, a diwan (religious congregation) was held at Bara Sikh Sangat in 172 Harrison Road. Gurdit Singh, the organiser of Komagata Maru expedition to Canada, who had shifted to Calcutta that year, delivered a "fiery speech" before 600 men and women, citing "indignities" inflicted on the Sikhs by the government. An "objectionable" Gurumukhi leaflet, printed at the Kavi Kuthia Press of Bhabanipur, was circulated. Signed by Teja Singh Sorabha and Inder Singh Hoshiarpuri, it stood for a theology of liberation: "The Guru was born to deliver the labourers from the oppressions of the rulers. The same oppressions are committed now as in those days...Be united. Listen to the commands of the Guru. Realise the ideal of the Guru. Unite as the labourers have done all over the world and throw off the yoke of slavery. Awake and arise. Break the fetters of slavery." The hand-bill urged the Sikhs to subscribe to Kirti (Worker), a labour journal published by communists in Punjab. They were also asked to join Bengal Kirti Dal located at 29, Russa Road, North, Bhabanipur. It was to be a local branch of the Kirti-Kisan Party of Punjab, a counterpart of Workers and Peasants Party of Bengal (WPP); both were open organisations of the illegal Communist Party of India (CPI). The police sensed a joint influence of "Ghadar revolutionaries" and "the Bolshevik flavour" behind this initiative. A Bengal Kirti Dal Committee was established in December 1927. A “Sikh Agent” reported on a private meeting of "Kirti Dal Committee" held on 3 December 1927, at 29 Russa Road, at the residence of Mahendra Singh, a bus owner and a member of the Gurudwara Prabandhak Committee, Bengal. Among the office bearers elected to the Executive Committee were Balwant Singh Granthi of the Ballygunge Gurudwara, Bhag Singh, a bus driver, Genda Singh, a bus driver of the Tramways Company, Gurdayal Singh Patiala, of 10 Justice Dwarka Nath Road, a medicine dealer, Mahendra Singh, a bus driver and owner and Sawadagar Singh of Kavi Kuthia Press. No programme of work was drawn up but President Teja Singh Sorabha (Safri) and Secretary Inder Singh Hoshiarpuri, a motor driver from 9 Alipur Road were working on it.

The overwhelmingly working-class composition of Bengal Kirti Dal attracted government attention from its inception. The police hoped the group will be ineffective. A letter from 14 Elysium Row by S. S. H. Mills, Deputy Commissioner, Special Branch of Calcutta Police, to Cleary, Personal Assistant to Director, Intellingence Bureau, Home Department, New Delhi with copy to DIG, CID, Special Branch, Punjab, Lahore and F.P. McKinty, Intelligence Branch, Bengal Police forwarded the report of the Sikh agent and observed: "My own impression is that this Dal will come to an untimely end, unless it is supported with funds from outside. I am... in close touch with its activities. Teja Singh Safri, is, of course, well known, and I am endeavouring to ascertain the antecedents of Inder Singh Hoshiarpuri." 
In April, a worried letter from CID, Lahore reached Cogwill of IB in Calcutta:

Information has been received that Calcutta is being made a centre of the Kirti Group, that the Bengal Kirti Dal is in close touch with Bengal revolutionaries on one side and with the Kirti group in the Punjab on the other side, and that messsages are being exchanged between Calcutta and Amritsar through special messengers. It is further reported that the organizers of the Kirti Movement are trying to set up a regular system of communication between Calcutta and the Punjab, as they are afraid of their correspondence being censored by Government if sent by post.... I am desired to pass on the above for your information and any action you may deem necessary in the matter. The Intelligence Bureau, Simla, is also being informed.

Soon, the CID was accused of trying to crush the nascent Kirti Dal through infiltration, harassment and persecution. Genda Singh, employed by the European owned Calcutta Tramways Company, was threatened with dismissal unless he refused to resign from his post as President of Kirti Dal. Consequently, Genda Singh had to give up his employment rather than submit to the pressure. Tight police control and surveillance on Sikh dissenters meant closing in on political activists through indirect routes of victimisation and removal when legal means of prosecution were not at the disposal of the colonial authorities.

By early August, the connections between Bengal Kirti Dal and Workers and Peasants Party of Bengal were being keenly followed. Sohan Singh Josh, a Ghadar revolutionary-turned-early communist leader from Amritsar wrote to Muzaffar Ahmad, one of the early communist leaders from Bengal and India, requesting him to write for Kirti which Muzaffar read regularly. Josh wanted Muzaffar to write an article "giving your views" on All India Workers and Peasants Party's constitution in the making or "some other article" by 15 August: "You should do it positively as the articles of all the comrades are being published in the columns of the "Kirti" save and except that of yours." He acknowledged receiving Ganabani, the mouthpiece of Bengal WPP edited by Muzaffar and asked him to underline important sections in red, possibly for the purposes of translation and discussion. He promised to do the same when sending Kirti. The police instantly surmised: "It is pretty clear from this that the "Kirti Dal" of Amritsar is getting in closer touch with the Workers' and Peasants' Party in Bengal." Meanwhile, gathering information on and stereotyping of leftist opponents continued. The Punjab police sent its views on Kirti Dal as a grouping of "Sikh extremists" from Amritsar. Sohan Singh Josh was described as "weak and ineffective" while Baba Bhag Singh Canadian, a Ghadar veteran, was projected as "a drunkard and a womaniser." The surveillance report from Punjab thought the organisation was without prospects and could only become influential in the future if it became actively involved in agrarian issues, particularly the question of landownership.

In 1928, Bengal Kirti Dal's office was shifted to Gurdit Singh's house at No 27/2 Ashutosh Mukharji Road in Bhabanipur from its previous location at 35/17 Padmapukur Road. Later that year, Sohan Singh Josh visited Gurdit Singh and other members of Kirti Dal. He had arrived in 
Calcutta and headed for the Bengal WPP office; local communist activists, including prominent figures such as Abdul Halim and Dharani Goswami escorted him. A Special Branch officer reported on 5 September 1928, regarding the watch over the Bengal WPP office at 2/1 European Asylum Lane, Calcutta:

This morning at about 8 A.M a Punjabi aged about 30/35 years, tall, having moustaches and beard, fair complexion, strong build wearing long coat (Achkan) pyjama, nagra shoes and a pagri, came to the above place with a small bedding and a handbag in a 2nd class phaeton. This Punjabi was searching for Muzaffar Ahmed of 2/1, European Asylum Lane, of "Ganavani" office, and his name was ascertained to be Sohan Singh. He was coming from the Punjab. The watchers were instructed to keep an eye over him.

The next day Assistant Sub-Inspector Brojendra Kumar Roy Chowdhury of Special Branch reported on "Suspect Sohan Singh who stopped at 2/1 European Asylum Lane," following him to various addresses of Sikh left activists in the city till he left, late in the evening by Punjab Mail, having been escorted to Howrah Station by Halim and two Punjabi activists (IB 185/1928 $(87 / 1928))$.

That "suspects" mingling as "comrades" were a source of anxiety. Their transregional, transcontinental and internationalist connections were apparent when Special Branch noted that 100 copies of "India and the next war" by Agnes Smedley were in possession of Muzaffar Ahmad of Bengal WPP: "they were probably brought here during the last visit of Sohan Singh Josh of the Amritsar Kirti Dal." By October, "several visits" had been "exchanged” between Dharani Goswami of Bengal WPP and Prithi Singh of the Bengal Kirti Dal, the focus being the latter organisation's activities. Dharani had apparently advised the inclusion of Bengali members, with the aim of popularising the Dal at the local level. The Executive Committee of the Dal, according to the police was thereby "re-constructed" with Mohini Mohan Haldar as President, Genda Singh as Vice President, Tincori Banerji as Secretary, Inder Singh Hoshiarpuri and Prithi Singh as Assistant Secretaries and Balwant Singh Granthi as Treasurer (IB 185/1928 (87/1928)). Prithi Singh was later identified as a former apprentice in French Motor Car Company at Bhabanipur who had arrived in Calcutta at the end of 1926. He had read up to Middle English Standard, studied Civil Engineering, had served in Mesopotamia for 3 years during the war and returned after Armistice (IB 111/28 (191/28)). The Bengali office-bearers were expected to help enlist Bengali members. Mohini Mohan Haldar was reported to be a Homeopathic practitioner residing at 275 Kalighat Road and a member of the South Calcutta Congress Committee. Tincori, a clerk of the Bengal Nagpur Railway's office at Garden Reach was the assistant secretary of the Bengal Nagpur Railway labour union and lived at 6/1 Kali Lane. Both were acquaintances of Prithi Singh who had encouraged them to join the Dal. Balwant Singh was suspected of making arrangements "to preach communistic and revolutionary principles among the rank and file of Sikhs" by bringing out a fortnightly newspaper called "Lal Jhanda" (Red Flag), the print-organ of Bengal Kirti Dal in 
Gurumukhi script and guided by the principles of the Dal's headquarters in Amritsar (IB 185/1928 $(87 / 1928))$.

\section{Combined Actions}

Gurdit Singh had become active in labour and community meetings soon after his arrival in the city. His memoirs on Komagata Maru's voyage was translated and printed from Calcutta (IB $111 / 28(191 / 28))$. He also started civil proceedings against the government regarding the ship's journey and treatment of the passengers during 1914. His activities, along with the wider political developments in which Sikh workers and migrants engaged, came to be watched each week by police agents. On 8 January 1928, "intemperate speeches" were made by Pandit Murali Dhar of Kanpur and Gurdit Singh, at a Sikh diwan held in Ballygunge Gurudwara. Murali Dhar stated that in 1925 he had "declared himself free and would make India free at any cost," being a resident of a part of the country where the mutiny of 1857 had broken out. If the Sikh soldiers had not fought against the mutineers, the "red-faced men" would not have been able to rule India. The speaker appealed to the Sikhs to join in the cause of freedom, as "death was preferable to a life of shame." He ended his speech with a reference to imperialist incursions into China, appealing to all Indians not to assist the British in any way against the Chinese people. Gurdit Singh endorsed his views. He thought the Sikhs had committed a great sin by helping the English to suppress the mutiny. At a private meeting of 20 Sikh bus and taxi owners held at Gurdit Singh's Bhabanipur residence on 10 February, it was decided to form a Sikh motor syndicate to check "the alleged zulum of the Police." A Khalsa Motor Syndicate emerged with Gurdit Singh as President of the owner's association. On $11 \mathrm{March}$, at a meeting in Ballygunge Gurudwara with the aim of popularising the syndicate, "Gurdit Singh, as usual, seized the opportunity of hurling invective at the police, whom he criticised as "demons let loose" and "parasites sucking the life-blood of the people." The police, he alleged, went about in Calcutta sending up the poor Sikh drivers on petty charges, and allowing the more wealthy who were able to pay bribes to go scot-free." ${ }^{8} \mathrm{He}$ was arrested on 16 March to answer a charge of delivering a seditious speech at Mirzapur Park on 3 March. He was granted bail and ultimately acquitted by the Chief Presidency Magistrate. ${ }^{9}$ He issued a pamphlet in Gurumukhi drawing attention to his continued persecution by the state "to hamper him in the civil suit, in connection with the "Komagata Maru" case, which he has first instituted in the High Court." The response, in his support, was immediate. On 22 April, at a diwan held at Ballygunge Gurudwara, and attended by 350 men and 200 women, a speaker proposed, that in the event of a future war, Sikhs should refrain from assisting the Government and remain passive, having been subjected to

\footnotetext{
${ }^{8}$ IB File numbers suppressed at the time of consultation. Contains "Reports on the Political Situation and Labour Unrest in Bengal" from 1928 to 1932.

${ }^{9}$ IB File numbers suppressed at the time of consultation. Contains "Reports on the Political Situation and Labour Unrest in Bengal" from 1928 to 1932. Annual Report on the Police Administration of the Town of Calcutta and its Suburbs for the year 1928.
} 
many indignities after having helped in the last war. Gurdit Singh agreed and "regretted that Sikhs, whose heads were dedicated to the service of the Gurus, should serve in the army for a pittance of Rs.15 month and should slaughter human beings. What was worse still, they joined the C. I. D. and carried to the ears of the authorities stories against their own countrymen." He sarcastically declared that British soldiers deserved no rewards, for they served their king, but Indian soldiers reserved awards for killing their compatriots in the interest of the British Raj. He concluded that he could be "sent to jail for saying these things, but he was not afraid as they were already confined in a bigger jail." These views matched some of the radical analyses on empire, colonial governance and the repressive state apparatus stemming from the left, and worried the authorities. The police encouraged Raghubir Singh, projected as a moderate and a loyalist, to successfully expel Gurdit Singh from a position of influence in the owners' association. Since the association was composed of owners, the police could easily outmaneuver Gurdit Singh. This was evident from a report on a Bus Syndicate meeting held on 20 July on the roof of its Bhabanipur office at 79 Padmapukur Road. Raghubir Singh expressed satisfaction over Police Commissioner's sympathetic attitude to their deputation. The meeting requested owners to make the drivers obey the orders of the traffic police. The police happily noted that the syndicate had "cooperated with the police in dealing with taxi and bus traffic in the neighbourhood of Chowringhee, and the results so far have been very satisfactory."

Other speakers in Gurdit Singh's milieu, representing the Sikh community from below, joined and championed the communist-led left movement in Punjab, locally represented by Bengal Kirti Dal. Gurdit Singh endorsed and participated in these efforts. At a diwan held at Ballygunge Gurudwara on 15 January 1928 in the presence of about 500 Sikhs, Mahtab Singh and Mangal Singh exhorted the Sikhs to be ready to sacrifice their lives in the cause of their religion and country. The latter's appeal also held up Soviet Russia as an example to follow. On 1 July, at a diwan held in Bakulbagan Gurudwara and presided over by Balwant Singh Granthi, around 260 persons, 60 of whom were women, gathered. "The object of the diwan was to advocate the necessity for joining the Kirti Dal. Speeches were made by Bhag Singh, Assistant Secretary of the Dal, and Prithi Singh, a member. The speeches were anti-Government in tone, but there was nothing unusual or alarming about them." Prithi Singh also printed and circulated a Bengal Kirti Dal membership application form in Gurumukhi from Kavi Press, Bhabanipur. ${ }^{10}$ Soon, plans were afoot to bring about an "amalgamation" of the Bengal Kirti Dal with its regional counterpart, Workers and Peasants Party of Bengal. This was evident on the eve of a proposed All-India Conference of the different regional groups led by Communist Party members. By late 1928, the police were well aware that the Bengal communists, with the help of Kirti activists, were planning to host an AllIndia WPP meeting alongside the annual Congress session to be held in December at Calcutta (IB $185 / 1928(87 / 1928))$.

\footnotetext{
${ }^{10}$ IB File numbers suppressed at the time of consultation. Contains "Reports on the Political Situation and Labour Unrest in Bengal” from 1928 to 1932.
} 
Muzaffar Ahmad, who had travelled to Bombay and been unable to meet Sohan Singh Josh when the latter visited Calcutta during early September, wrote to Josh on 5 November 1928: "I draw your attention to the fact that Sikhs in Calcutta form a Bengal Branch of the Punjab Party. This is really ludicrous. I held a Conference with some of them and what I understand is that the workers themselves are not unwilling... I will make the Bengal Kirti Dal at least a branch of the Bengal Party...Also print a notice in the Punjabi addressing the Punjabi workers, Sikhs, Hindus and Mussalmans in Calcutta and near about." He wanted the Kirti members to deal with two specific points in the notice: what Kirti Dal stood for and the relationship between different regional parties organised by the left. Muzaffar suggested that the notice should put forward the position that all the regional parties led by communists were working with the same principles and programme and will unite as one through the coming conference. Planning of the event led to joint activities. On 11 November, a public meeting of Sikhs was held in Calcutta under the aegis of the Bengal WPP. The aim was to publicise the Party's programme among the workers, particularly Sikh migrants and obtain their assistance during the forthcoming All-India Workers and Peasants Party Conference. Philip Spratt, sent to India by Communist Party of Great Britain (CPGB), to help communists in India spoke first and explained the programme of the party, advising labour organisations to join ranks. Other speeches focused on the oppressions of the colonial state as well as Indian money-lenders, zamindars and capitalists. At the end of the month, Spratt, Muzaffar Ahmad and Executive Committee members of Bengal WPP made further practical plans to work closely with Kirti members in view of the coming merger in December and chose Sohan Singh Josh as the conference president. The police thought Josh had been instrumental in convincing Bengal Kirti Dal members to work with Gurdit Singh when he briefly visited the city. Josh believed this cooperation will strengthen the group (Roy 1998, 51-53). A meeting of the reception committee of All-India WPP Conference was held at European Asylum Lane on 28 November where P. Dinda presided in the presence of Muzaffar Ahmad, Abdul Halim, Philip Spratt, Dharani Goswami, Nirod Chakraborty, Balwant Singh and Genda Singh. The discussion touched on the number of delegates who will be coming, the method of voting and other details.

This was followed, a month later, by the hosting of what was described by the police as "the first conference of its kind in India." Among prominent representatives from Bengal to United Provinces to Bombay were noted the presence of activists from Punjab, including Ferozuddin Mansoor, Sohan Singh Josh, Mangal Singh and Gurdit Singh. B.F. Bradley and Philip Spratt of CPGB, active respectively in Bengal and Bombay and Jack Ryan, a communist from Australia, representing the Pan-Pacific Trade Union Congress attended the conference, emphasising its internationalist orientation. Sohan Singh Josh allegedly delivered an "objectionable" presidential address at Albert Hall, College Street, a hub of the anti-colonial public sphere in the city, where 300 left delegates had congregated. He "began by referring to the "Komagata Maru" incident at Budge Budge, on which occasion, he said, Punjabis had been brutally murdered. He then attacked the Congress policy and said that they must demand complete independence." He envisaged a "coming war" between the communists and the British Empire; once direct combat against British capitalism began, mass strikes and sabotage were to be adopted as methods, and all means of 
communication destroyed so that the British government faced the combined attack from two sides by Soviet Union and the communists from India. In anticipation of such a day, he advocated launching a campaign to discourage potential recruits from joining the colonial army, turning to the imperial practice of enlistment drives in Punjab and in keeping with similar views long circulated by anti-colonial Punjabi circles. The militant mood at the conference was observed along with a march across the city at the conclusion of the event to publicise left activism; the procession responded to anti-capitalist, anti-imperialist slogans, demanded a workers' government, and carried 40 red flags (IB 210/1927 (23/1927)). The conference, held alongside the annual session of Indian National Congress (INC), also had another purpose. The left activists, trade-unionists and workers "invaded" the Congress conference tent and demanded the adoption of "complete independence" as the declared goal of Indian nationalism; under gathering pressure from below, the Congress leaders agreed to consider and adopted this as policy in the following annual session at Lahore (Chatttopadhyay 2011, 180).

The colonial state was already prepared to strike at the militant labour and communist movement. Speeches were being recorded in detail, and perhaps embellished to suit the imperial strategy of uprooting the left opposition from the political landscape. Hansen, Deputy Commissioner of Calcutta Police felt a "distinct advance" in proceeding against the communists and leftists could be made on the basis of views expressed at All-India WPP conference. After communist and militant labour leaders were arrested in March 1929 and stood trial at Meerut, a "legal defence fund" was established in Calcutta to raise money for those on trial and campaign against the arrests; the initiative involved activists from a Sikh background. In his letter to the Central Defence Committee of Meerut prisoners in Delhi, Abdur Rezzaq Khan, Secretary of Meerut Trial Defence Committee in Bengal wrote that the fund-raising body formed in May contained Balwant Singh of Bengal Kirti Dal. The correspondence between Punjabi and Bengali communists continued, indicating a relationship of shared concern and personal warmth in the face of repression. In April 1929, Halim wrote to Ferozuddin Mansoor enquiring on the state of the communist party in Punjab, stressed on a need for renewed campaign among workers and peasants following the Meerut arrests, reported his ill-health and expressed his "heartfelt" love to be conveyed to Baba Bhag Singh Canadian. Ferozuddin replied that the fight had to go on and Bhag Singh Canadian was keeping well.

Though Gurdit Singh briefly turned left before moving to a position of permanent affiliation with the Congress, the handful of activists who had joined Bengal Kirti Dal, remained within the communist fold. Inder Singh Hoshiarpur, Genda Singh, Balwant Singh, Ajit Singh and Prithi Singh were regarded by the colonial authorities as "Sikh members" of the Communist Party of India, active among the diaspora living in Calcutta and Budge Budge, especially transport workers from Punjab (IB 210/1927 (23/1927); IB 210/27 (41/27)). In late April 1930 an enquiry was made by Special Branch, Calcutta Police regarding a letter written by Prithi Singh from 118 Manoharpukur Road, Bhabanipur to Hari Singh, a carpenter engaged at Lilooah railway workshop in Howrah. Prithi Singh had wanted Hari to print "ABC of Communism" in Gurumukhi, promised to send Rs.100/- for this purpose and declared that the translated manuscript covered 4 exercise 
books. Confidential enquiries at Lilooah workshops yielded nothing. Hari Singh could not be traced (IB 185/28 (87/28). During the early 1930s, Abdul Halim was in "close touch" with the local communists from a Sikh background. In 1933, the government thought he was making plans with his Sikh comrades to import Russian oil cheaply via Budge Budge and utilise the profit for spreading communist propaganda in India. Since oil-products imported into Calcutta passed through the oil depot at Budge Budge, surveillance was mounted on the possible arrival of Soviet ships carrying petroleum and propaganda, and Sikhs with communist convictions connected with the transport of oil in South Bengal. However, the British official requested to keep watch revealed the paradox of capitalism-in-crisis and the submerged yet ever-present inter-imperialist competition; he felt such a development was to be welcomed as Russian oil could only drive the depression-era high prices of petroleum downwards. He labeled "current" prices as "scandalously high" as the market was controlled by American corporate monopolies like Standard Oil (IB 111/28 (191/28)). Halim was also suspected of using Harnam Singh, a communist from a Sikh background as a courier of confidential communist correspondence; in a letter to Muzaffar, Halim had mentioned sending some letters through him (IB 210/1927 (23/1927)). In the early 1930s, Mangal Singh, who had been dismissed from Tata Steel Works at Jamshedpur was in touch with several activists in Calcutta, including Abdul Halim, the Bengali communist leader Somnath Lahiri, and Santa Singh, described as a communist based in Calcutta. He also maintained contact with Munsha Singh Dukhi, a revolutionary poet with a Ghadar past who had established the radical Kavi Kuthia press at Bhabanipur. Viewed as "an experienced and influential labour agitator" in the language of state, Mangal Singh worked with Manik Homi, a Parsi worker and Phanindra Nath Dutta, an unemployed youth from a bhadralok background who had studied engineering at the nationalist technical school at Jadavpur in Calcutta. The latter corresponded with Halim on action. His brother, Nagendra Chandra Dutta, a political prisoner had died in jail during the late 1910s. Phani wrote to Halim in 1934 that he and "Comrade" Mangal Singh were organising unemployed workers and about a thousand had gathered at a meeting in Jamshedpur where the causes and remedy of unemployment had been explained in leftist terms (IB 210/27 (41/27)). Though Muzaffar Ahmad spent the first half of the 1930s in prison, the police thought he had been keen to organise Sikh janitors and recruit them to the communist party (IB 168/22 (1935-51)). The cordial relationship between communist organisers and Sikh labour activists survived into the 1940s. Sardar Kehr Singh, a Ghadar veteran from Canada, member of Executive Committee of Bus Drivers' Union and volunteer at a Congress meeting in 1945, defended communists against the accusation that the former had cut microphone wires to sabotage a Congress mass meeting. He stressed on the unity of all anti-colonial forces as the "need of the hour" and regarded "baseless accusations against individuals and parties" as undesirable. ${ }^{11}$

The communist activists from a Punjabi Sikh background in Bengal during the inter-war period continued to represent a militancy inherited from their struggles as migrant workers. Saroj Mukherjee, a communist leader from Bengal recalled Genda Singh as an active organiser of CPI-

\footnotetext{
${ }^{11}$ See: What happened at the Deshapriya Park meeting and thereafter? 1945. Calcutta: CPI pamphlet.
} 
led Transport Workers Union in the early 1930s. In 1934, Genda Singh was arrested for delivering a speech against the state at a communist rally in the maidan. He was speaking at a time-honoured protest spot in Calcutta, the space in front of the Ochterlony Monument, a colonial landmark later renamed Shahid Minar (Martyr's Column). Sentenced to rigorous imprisonment on the charge of sedition, he and other communists were stripped of their status as political prisoners and treated like ordinary convicts inside the jail premises. He had appealed to the crowd to uproot the British Raj and throw the regime into the sea (Mukhopadhyay 1993, 61, 78).

\section{Conclusion: The Long Memory}

In the inter-war period, the expatriate militancy of the war-time Ghadar Movement and the symbolically defiant references to Komagata Maru surfaced in labour rallies and speeches of left and militant labour activists. They appeared as sources of inspiration and as traumatic memory incorporated within the repeated drives for fresh mobilisation against colonial capital and resistance to imperialist state authority. They also conveyed an explicit vision of an alternative society after decolonisation, one that was no longer bound by the rule of private property and profit.

Genda Singh had cited, perhaps unconsciously, the motif of the ocean, associated with Komagata Maru and other ships of Ghadar "sedition," (Chattopadhyay 2016, 203-222) carrying migrant workers across long stretches of water. He had inverted the water-bound experience of Sikh migrant workers and consigned the Empire to the sea. A direct reference to the experiences aboard Komagata Maru could be found in the lectures of Gurdit Singh. Though leaving behind his early communist association in the city, he had joined a socialist labour current present within and subordinate to the Congress nationalist platform. Gurdit Singh continued to recall the ship's journey in public meetings. In June 1932, he revisited Budge Budge as the President-Elect of a district labour conference; he was welcomed on behalf of the local population. A chorus of little girls started the proceedings with a song dedicated to labour. Ideological differences surfaced when the sole communist speaker Abdul Momin criticised Gandhi and the Congress leadership for compromising with capitalists. Some tried to object while he was speaking but Gurdit Singh allowed him to continue. Others echoed the wider contours of the communist position. Sudhin Paramanik who addressed the meeting in Bengali as chairman of the conference reception committee, spoke of the hardships endured by Gurdit Singh and his struggles on behalf of labour, welcoming him on behalf of the people of Budge Budge. He spoke on the oppressive labour relations practiced by different oil and petrol concerns at Budge Budge. Referring especially to the misbehavior and exploitation of Burma Shell Company at Budge Budge and Golmuri, he requested the conference to adopt a policy to combat the management. Speaking of a "rotten society" and its "tyrannical administration," he pronounced: "Time had...come for the capitalists to be careful as to how they behave with their labourers." Condemning capitalism and imperialism he declared 
that their conjoined hold will be overthrown, that capital was not the master of the working-class, and that the Meerut Trial showed how afraid the capitalists were of workers.

Gurdit Singh was overwhelmed by a sense of déjà-vu while addressing the assembled crowd of 4000 men and women: "he was glad to address the Budge Budge people in their own place, he loved Budge Budge as he was intimately connected with the place... described how he and the rest of the crew of the Komagata Maru were treated by the Canadian as well as the English Government." He recalled his direct experience of contesting, within legal bounds, colonial racism and the discriminatory navigation and immigration laws applied against people of dark skin, and being persecuted by the state. He consciously linked and situated this past within a personal and wider frame of social resistance from below; he stated he was a born peasant who had spent his life among workers and planned to spend what remained of it in the same way. While opposing capitalism and empire-building, he praised Soviet Union as a workers' state, envisaged India as a country ruled by workers in the future and advocated unity of labour, free of factional differences, so that workers could become "invincible." The speech, delivered in Urdu, was translated into Bengali by Jalaluddin Hashmi, a Congress trade-unionist, for the benefit of those who could not scale the language barrier. The latter went on to add that the task of the workers' movement was to defy those in power (IB 497/1927 (168/1927)). Not merely as an individual, unique "episodic" memory, Gurdit Singh was sharing his experience on the ship with others as memory-knowledge, rooted in a rejection of the colonial labour regime. Activists and workers from different ethnolinguistic-religious and political backgrounds, as listeners, absorbed this as transmitted experience, to be claimed and shared (IB 185/28 (87/28); IB 497/27(168/27)). ${ }^{12}$ For them, the past was unfolding in the present, urging action and individual memory was taking on the form of class memory.

\section{References}

Assmann, Aleida and Linda Shortt, eds. 2012. "Introduction." In Memory and Political Change, edited by Aleida Assmann and Linda Shortt. New York: Palgrave MacMillan.

Banerjee, Himadri. 2012. “The Other Sikhs: Punjabi-Sikhs of Kolkata.” Studies in History 28 (2): 271-300.

Chattopadhyay, Suchetana. 2016. “Closely observed ships.” South Asian Diaspora 8 (2): 203-222.

\footnotetext{
${ }^{12}$ Memory-formation of individuals is explored by E. Tulving 1972. An analysis of workers' memory of past struggles in the North Indian context can be found in Joshi 2003, 11, 236. For an understanding of the social dimensions of memory, see Fentress and Wickham 1992. For discussions on memory and action, see Assmann and Shortt 2012.
} 
Chatttopadhyay, Suchetana. 2011. An Early Communist: Muzaffar Ahmad in Calcutta. Delhi: Tulika.

Deepak, B. R. 2001. India China Relations: In the first half of the 20th Century. Delhi: A. P. H. Publishing Corporation.

Fentress, James and Chris Wickham. 1992. Social Memory. Oxford: Blackwell.

Johnston, Hugh. 1995. The Voyage of the Komagata Maru: The Sikh Challenge to Canada's Colour Bar. Vancouver: University of British Columbia Press.

Joshi, Chitra. 2003. Lost worlds: Indian labour and its forgotten histories. Delhi: Permanent Black.

Mukhopadhyay, Saroj. 1993. Bharater Communist Party o Amra (Communist Party of India and Ourselves), Vol. I (1930-41). Calcutta: National Book Agency.

Puri, Harish K. 1983. Ghadar Movement: Ideology, Organisation and Strategy. Amritsar: Guru Nanak Dev University Press.

O’Malley, L.S.S. 1913a. Census of India 1911, Volume VI, City of Calcutta, Part I: Report. Calcutta: Bengal Secretariat Book Depot.

O’Malley, L.S.S. 1913b. Census of India 1911, Volume VI, City of Calcutta, Part II: Table. Calcutta: Bengal Secretariat Book Depot.

Ramnath, Maia. 2011. Haj to Utopia: How the Ghadar Movement Charted Global Radicalism and Attempted to Overthrow the British Empire. Berkeley: University of California Press.

Roy, Subodh, ed. 1998. Communism in India: Unpublished Documents 1925-1934. Calcutta: National Book Agency.

Sarkar, Sumit. 1983. Modern India 1885-1947. Delhi: Macmillan.

Sood, Malini. 2000. Expatriate Nationalism and Ethnic Radicalism: The Ghadar Party in North America. Hamden: Garland Publishing, Incorporated.

Tatla, Darshan S., ed. 2007. Voyage of Komagata Maru or India's Slavery Abroad. Chandigarh: Unistar Books/Punjab Centre for Migration Studies. 
Thompson, W. H. 1922. Census of India, 1921, Volume VI, City of Calcutta, Part I: Report. Calcutta: Bengal Secretariat Press.

Tulving, E. 1972. "Episodic and semantic memory." In Organization of Memory, edited by E. Tulving \& W. Donaldson. New York: Academic Press, 382-402. 